\title{
Diversity and Abundance of Macrozoobenthos in the Coastal of Puteri Sidokelar Lamongan
}

\author{
${ }^{1}$ Trisnani Alif, ${ }^{2}$ Yustika Aulia Rahma, ${ }^{3}$ Alfi Nur Wahidah \\ ${ }^{1,2,3}$ Program Studi Biologi, FMIPA, Universitas Billfath, YPP Al Fattah Siman, Sekaran, \\ Kabupaten Lamongan, Jawa Timur 62261 \\ Email Correspondence: trisnanialif@gmail.com
}

\author{
Article Info \\ Article History \\ Received:9 February 2021 \\ Revised: 9 July 2021 \\ Published: 25 September \\ 2021 \\ Keywords \\ Diversity; Abundance; \\ Macrozoobenthos, Coastal \\ of Puteri Sidokelar \\ Lamongan
}

\begin{abstract}
Diversity and abundance of macrozoobentos in Puteri Beach Sidokelar Lamongan. Macrozoobenthos are organisms that live on the bottom of waters, and are part of the food chain whose existence depends on the population of organisms at lower levels. This study aims to analyze the diversity of macrozoobenthos found on the coast of Puteri, Sidokelar Village, Lamongan Regency. Macrozoobenthic sampling using the transect method measuring 5 $m x 5 \mathrm{~m}$. The identification of this sample was carried out at the Biology Laboratory. Billfath University Lamongan using journa literature. The results of the study found 5 types of animals consisting of 4 types from the gastropod class 1 type from the class Bivalvia. Types of Cerithidea cingulata were the most common, with as many as 20 individuals. The least type was Gafrarium pectinatum which was found only in 1 individual. Diversity index $\left(H^{\prime}\right)$ in a moderate coastal ecosystem. The community is in a state of moderate stability or diversity with the number of individuals for each species is not uniform but no one is dominant $\left(1<H^{\prime}<3\right)$.
\end{abstract}

(C) 2021 Science Education Study Program FKIP Unisla Lamongan

Citations: Alif, T., Rahma, Y. A., \& Wahidah, A. N. (2021). Diversity and Abundance of Macrozoobenthos in the Coastal of Puteri Sidokelar Lamongan. Science Education and Application Journal. 3 (2).

\section{INTRODUCTION}

The coast is where land and sea meet. Asyiawati (2010) defines the coastal area as a meeting place for land and sea which is defined as an interface area or transition area where all kinds of processes that occur depend on the very intense interaction of land and sea.

Coastal and marine areas in Indonesia have strategic value in the form of potential natural resources and environmental services known as coastal resources. Coastal area resources are industrial lands that can increase economic growth in Indonesia (Marpaung, 2013).

The coastal area in the Paciran Lamongan District is an area that often has tourism activities, ship repair activities and cultivation activities (Arfiati, 2019). Especially at Puteri Sidokelar Beach, the number of activities in the habitat of macrozoobenthos is suspected to be the cause of the extinction of macrozoobenthos and the destruction of the coastal ecosystem.

Macrozoobenthos are organisms that live on the bottom of the waters, part of the food chain whose existence depends on populations of low-level organisms (Noortiningsih and Handayani, 2008). Macrozoobenthos is one of the most important groups in aquatic ecosystems due to its role as key organisms in food webs. Macrozoobenthos are invertebrates that can be seen with the naked eye and live in and around rocks at the bottom of the water. According to Fikri (2014) macrozoobenthos are invertebrate animals, living in or on large 
sediments or other substrates, macrozoobenthos are usually snails, crabs, oysters, shellfish and include large insect larvae.

Based on the problems described above, research is needed on "Diversity and Abundance of Macrozoobenthos on the Puteri Coast of Sidokelar Village, Lamongan Regency".

\section{METHODS}

The study was conducted from December 2020 to January 2021. The sampling location was on the Puteri coast of Sidokelar Village, Lamongan Regency. The sampling method used the line transect method. Macrozoobenthos were identified at the Biological Laboratory of the Faculty of Mathematics and Natural Sciences, Billfath University.

This research is a quantitative descriptive research using exploratory method which aims to determine the diversity of macrozoobenthos on the Puteri coast of Sidokelar village, Lamongan Regency. The steps for collecting data in this study were carried out in the following way:

1. Determination of the sampling location points by purposive sampling method where this study contained three line transects. The transect line was made by tying a raffia rope to a small wooden stick measuring one meter with a transect area of $5 \times 5$ meters drawn from the beach to the sea. Explanation of each transect:

a. Transect I: located on the beach

b. Transect II: between the beach and mangrove trees

c. Transect III: around the mangrove tree area

2. Sampling of Macrozoobenthos

Sampling of macrozoobenthos was carried out using the line transect method referring to the modified Yulihatul (2019) study.

Sampling was carried out on each transect using a shovel at low tide. The sample taken is then placed in a jam bottle containing a formalin solution and labeled.

3. Identification of Macrozoobenthos

Identification was carried out at the Biology Laboratory, Faculty of Mathematics and Natural Sciences, Billfath University using the Indonesian snail and shellfish identification book volume I and volume II (Indonesia Shell) (Dharma, 1988), Bouchard (2004), Zwart (1995) Oscoz et al (2011), Eisenberg (1981) and Abbott (1974).

4. Analisis data

a. Individual Abundance (KI)

The abundance of Makrozoobenthos was calculated by the Yasman (1998) formula:

$$
\mathrm{A}=\frac{x i}{n i}
$$

information:

$\mathrm{A}=$ Abundance (number of ind $/ 25 \mathrm{~m} 2$ )

$x i=$ number of individuals of the $i$-th species

$\mathrm{ni}=$ total area of the $\mathrm{i}$-th type of square found

b. Diversity Index $\left(\mathrm{H}^{\prime}\right)$

The most commonly used diversity index is the Shannon-Wiener diversity index which is applied to large random communities where the total number of species is known (Krebs, 1972) 
Information:

$$
\mathrm{H}^{\prime}=-\sum_{i=1}^{S} \quad \text { pi In pi }
$$

$\mathrm{H}^{`}=$ Diversity index

$\mathrm{S}=$ Number of species

$\mathrm{Pi}=$ Proportion of the number of individuals of a species (number of individuals of a species per number of individuals of all species)

The range of diversity index values, according to Lee et al (1978), the stability condition of a community is divided into 3 criteria based on the $\mathrm{H}^{\prime}$ index, respectively:

$\mathrm{H}^{\prime}<1$ : The community is in an unstable condition or low diversity with a non-uniform number of individuals and one species is dominant.

$1<\mathrm{H}^{\prime}<3$ : The community is in a moderate state of stability or moderate diversity with the number of individuals of each species not uniform but none dominant.

$\mathrm{H}^{\prime}>$ 3: Community in stable condition or high diversity with the number of

c. Uniformity index (e) individuals of each species is uniform and none is dominant.

Evenness index is used based on the Shannon-Wiener function to determine the distribution of each type of macrobenthic animal in the area of observation (Fachrul, 2007)

$$
\mathrm{e}=\frac{H^{\prime}}{H \max }=\frac{\mathrm{H}^{\prime}}{\ln S}
$$

Information :

$\mathrm{e}=$ Uniformity index

$\mathrm{H}^{\prime}=$ Shannon-Wiener Diversity Index

$\mathrm{S}=$ number of types

According to Odum (1993), the size of the Species Uniformity Index ranges from 01, where: $\mathrm{e}>0.6=$ high species uniformity $0.4<\mathrm{e}<0.6=$ medium species uniformity e $>0.4=$ low species uniformity.

\section{RESULTS AND DISCUSSION}

The macrozoobenthos found on each transect can be used to describe the types of macrozoobenthos in these waters. In general, the abundance of Makrozoobenthos found on the coast of Puteri (table 1) varies widely. It is known that transect 2 has the highest abundance of $18 \mathrm{ind} / 25 \mathrm{~m} 2$, on the other hand transect 1 or 3 has the same abundance of 11 ind $/ 25 \mathrm{~m} 2$.

Based on the results of research conducted on coastal ecosystems from transect 1 to transect 3 found 5 types of animals from the gastropod class. The species Cerithidea cingulata was the most commonly found, as many as 20 individuals spread across transects 1 and 3 , this is because this species is a native inhabitant of native mangroves and has a high tolerance for environmental changes, so that These organisms can survive and thrive. In addition, $\mathrm{C}$. cingulata is a species that has a high adaptability to environmental changes (Atnsari, et al. 2020). The lowest species found was class Bivalvia with the type Gafrarium pectinatum. This species is the least commonly found because only 1 individual is found. This is because Bivalves generally live by immersing themselves in the sand, so that in sampling it is suspected that not all of them can be filtered out. 
Table 1. Total Abundance (eng/25 m2)

\begin{tabular}{lccc}
\hline \multicolumn{1}{c}{ Species } & \multicolumn{3}{c}{ Transect } \\
\cline { 2 - 4 } & I & II & III \\
\hline Littorina littorea & 1 & - & - \\
Cerithidea cingulata & 10 & - & 10 \\
Cerithideopsilla alata & - & 3 & - \\
Turbo sparverius & - & 15 & - \\
Gafrarium pectinatum & - & - & 1 \\
\hline Quantity & $\mathbf{1 1}$ & $\mathbf{1 8}$ & $\mathbf{1 1}$ \\
\hline
\end{tabular}

Based on table 1, it is known that the diversity and uniformity index values on transects I and III show the same results, namely $\mathrm{H}^{\prime}$ is around 0.3 and $\mathrm{e}^{\prime}$ is around 0.4 . Where diversity is classified as low or $\mathrm{H}^{\prime}<1$ where the community is in an unstable state or diversity is low with a non-uniform number of individuals and one species is dominant. In transect II, the diversity and uniformity index values showed that $\mathrm{H}^{\prime}$ was around 0.6 and $\mathrm{e}^{\prime}$ was around 0.9. The diversity index of transect II is low but the species uniformity index is high. The low diversity of species on the Puteri Klayar beach is due to the contamination of sea water quality by residents' waste. According to Nisrina (2016) that the low index of macrozoobenthos diversity on the coast is due to water quality pollution. In addition, according to Fachrul (2007) states that the diversity index category based on the ShanonWiener equation is stated to be very high and not polluted with a value $>3$, high and lightly polluted ranging from $2-3$, low and half polluted ranging from $1-2$, very low and heavily polluted ranged $<1$. The high value of the uniformity index is due to the low value of the diversity of a species (Indriyanto, 2010).

Table 2. Index of Species Diversity and Uniformity inCoastal Ecosystems

\begin{tabular}{ccccc}
\hline Transect & Number of species & $\begin{array}{c}\text { Number of } \\
\text { individuals }\end{array}$ & H' & e \\
\hline I & 2 & 11 & 0,3 & 0,4 \\
II & 2 & 18 & 0,6 & 0,9 \\
III & 2 & 11 & 0,3 & 0,4 \\
\hline
\end{tabular}

The following is a description of the species on the coast of Putri Sidokelar based on classification, morphology, and ecology. 
Table 3. Details of the Species Obtained

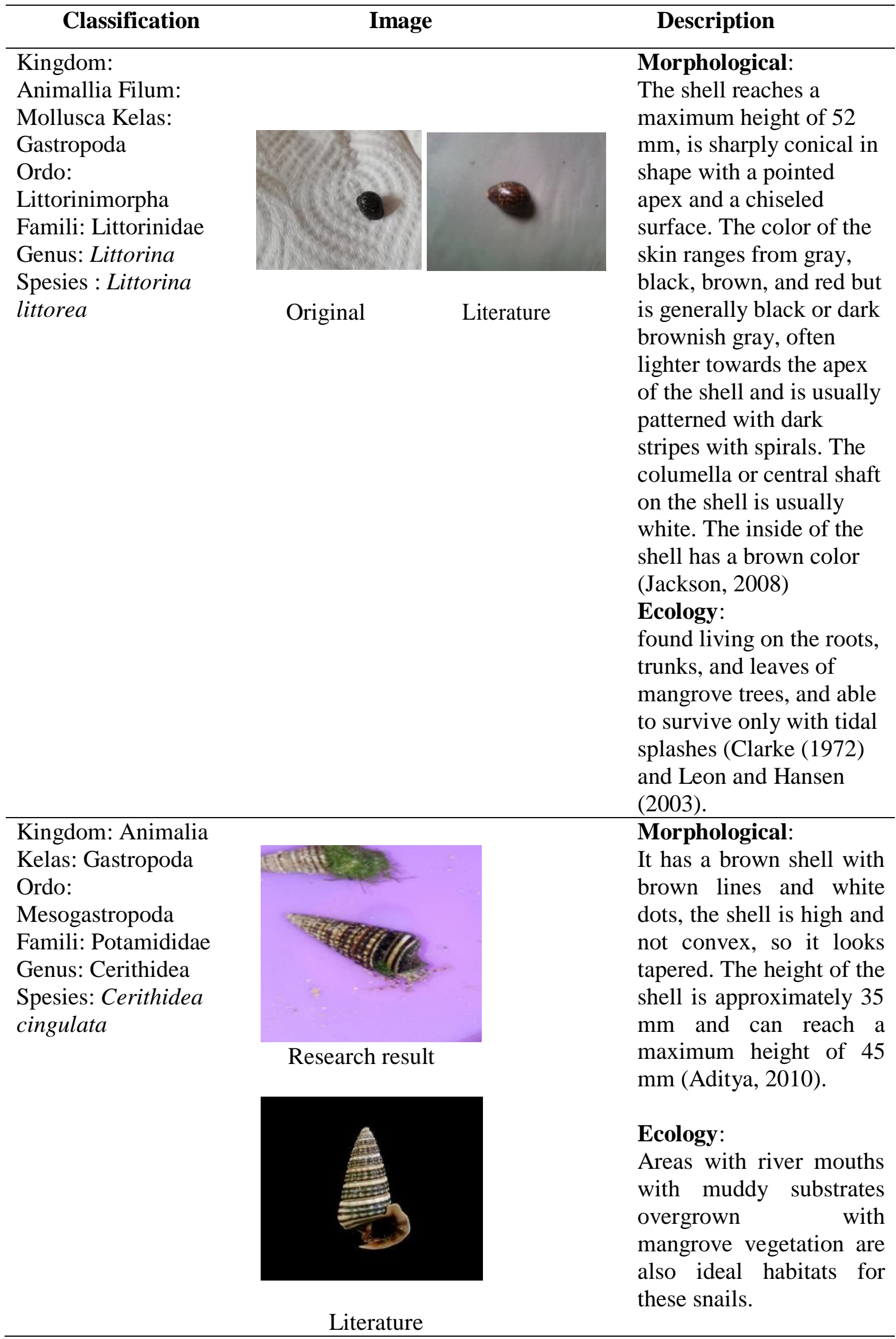


Kingdom:

Animalia Filum:

Mollusca Kelas:

Gastropoda Ordo:

Famili: Potamididae

Genus:

Cerithideopsilla

Spesies:

Cerithideopsilla alata

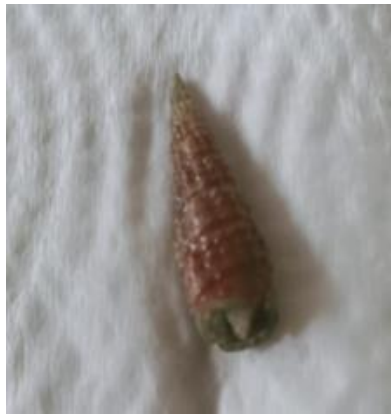

Research results

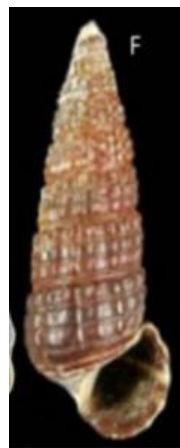

Literature
Morphology:

Small to medium in size with many whorls, coneshaped and pointed apex. The shell is dark brown black. The three spiral ribs line up and intersect with the axial ribs on each whorl. Among the three spiral ribs, the bottom rib is usually yellowish brown, while the other two spiral ribs are dark brown. The length of the shell is 3.73-1.13 and the width of the shell is 1.79-0.18 $\mathrm{cm}$.

Ecology:

Habitatnya ditemukan di dalam substrat di sekitar tumbuhan mangrove. (Wahyuni et al., 2016)
Kingdom:

Animalia Filum:

Mollusca Kelas:

Gastropoda Ordo:

Trochida Family:

Turbinidae Genus:

Turbo Spesies:

Turbo sparverius

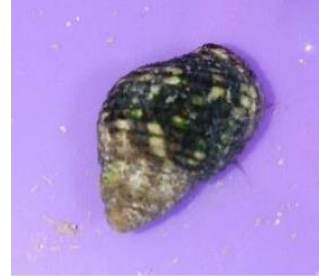

Research results

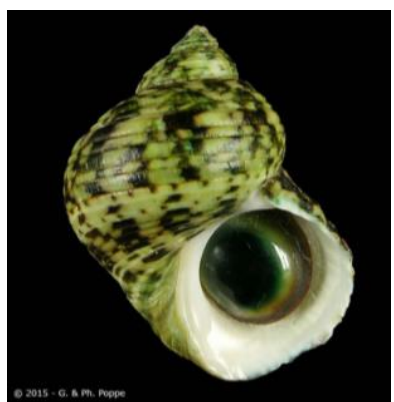

Literature

\section{Morphological:}

It has a dense, non-porous shell with various colors and can grow to various sizes between species. The shell of T. sparverius can grow to a length of 75 $\mathrm{mm}$. T. spaverius has an operculum color with black, brownish or greenish hues. The gasropod operculum Turbinidae serves as a passive defense structure against predators (Vermeij \& Williams, 2006).

\section{Ecology :}

Can be found in the neritic zone sea, deep sea, brackish water, rivers, lake streams and even at the mouth of caves (Saleki et al, 2016) 


\section{Kingdom: Animalia \\ Filum: Mollusca Kelas: \\ Bivalvia Ordo: \\ Venerida Family: \\ Veneridae Genus: \\ Gafrarium Spesies: \\ Gafrarium pectinatum}

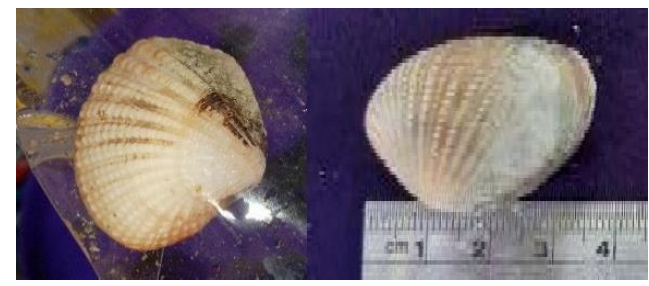

Research results
Literature
Morphology:

Has a shell measuring 6 $\mathrm{cm}$ long and $4 \mathrm{~cm}$ wide. The shell has protrusions as shown in the figure, namely the umbo and ligaments. It has a white shell with a brownish yellow motif resembling spots. Hard shell texture with lines. Shells consist of two sides, the side of the dorsal and ventral side Cossignani and Ardovini (2004)

\section{Ecology:}

Living under the sand on the coast of the intertidal zone to a depth of 20 meters

\section{CONCLUSION}

Based on the results of research conducted coastal ecosystems found 5 types of animals that consists of 4 types from class gastropod 1 species from class Bivalvia.type Cingulata Cerithidea is most commonly found as many as 20 individuals. The least type is Gafrarium pectinatum which is only found in 1 individual. The diversity index $\left(\mathrm{H}^{\prime}\right)$ in coastal ecosystems is low, while the uniformity index (e') is high in transect II.

\section{SUGGESTIONS}

It is hoped that further research will use other bioindicators so that it can be seen how far the tolerance level of macrozoobenthos towards environmental pollution is.

\section{ACKNOWLEDGMENTS}

The authors would like to thank Fita Fitriatul who has helped the research process to submit this manuscript.

\section{REFERENCES}

Aripin, Muthia Kanza. (2016). Kelimpahan dan Keanekaragaman Alga di Pantai Sindangkerta Kecamatan Cipatujah Kabupaten Tasikmalaya. Skripsi Program Studi Pendidikan Biologi, Fakultas Keguruan dan Ilmu Pendidikan. Universitas Pasundan Bandung

Atnsari, Anthoni, B.A., dan Shifa Helena. 2020. Kelimpahan dan Keanekaragaman Gastropoda di Kawasan Mangrove Desa Bakau Besar Laut Kabupaten Mempawah. Jurnal Laut Khatulistiwa 3(3): 97-104

Campbell, N.A., Jane, B., Reece, Lisa, U., Michael, L., Cain., Steven, A., Wasserman, Peter, V., Minorsky, Robert, B., Jackson. (2012). Biologi (Edisi Kedelapan). Jakarta: Erlangga

Clarke, R.B. 1972. Amazing World of Animals. Grolier Enterprise Inc. United States of America. Hughes, N.R. 1986. A Functional Biology of Marine Gastropod. School of Animal Biology. University College of North Wales, Bangor. 
Leon, R.A. \& I. G. Hansen. 2003. Biodiversity Associated with Mangroves in Colombia. ISME/GIOMIS Electronic Journal. 3(1).

Dewiyanti, I. 2004. Struktur Komunitas Moluska (Gastropoa dan Bivalvia) Serta Asosiasinya pada Ekosistem Mangrove di Kawasan Pantai Ulee - Lheue Banda Aceh NAD. Skripsi. Program Studi Ilmu Kelautan Departemen Ilmu dan Teknologi Kelautan, Fakultas Perikanan dan Kelautan. IPB. Bogor.

Dharma, B. 1988. Siput dan Kerang Indonesia jilid I dan jilid II (Indonesia Shell). PT. Sarana, Jakarta. Cummins. 1975. Indikator Makrozoobenthos. PT. TKCM. Tangerang

Fachrul, M.F. 2007. Metode Sampling Bioekologi. Bumi Aksara, Jakarta.

Indrawan M., Richard B., Premack., \& Jatna Supriatna. 2007. Biologi Konservasi. Edisi Revisi. Yayasan Obor Indonesia. Jakarta

Jeffries, M. and D. Mills. 1996. Freshwater Ecology. Principles, and Aplications. John Wiley and Sons, Chichester, UK.

Lind, O.T. 1979. Handbook of Methods in Limnology. Sec Ed. Mosby Company, St, Louis, Toronto, London

Marpaung, Anggi Azmita Fiqriyah. (2013). Keanekaragaman Makrozoobenthos di Ekosistem Mangrove Silvofishery dan Mangrove Alami Kawasan Ekowisata Pantai Boe Kecamatan Galesong Kabupaten Takalar. Skripsi. Prodi Ilmu Kelautan Fakultas Ilmu Kelautan dan Perikanan Universitas Hasanudin Makassar

Nisrina A. Izzah. 2016. Keanekaragaman makrozoobentos di pesisir pantai Desa Panggung Kecamtan kedung Kabupaten Jepara. Skripsi. Universitas Muhammadiyah Surakarta.

Putro S. P. (2014). Metode Sampling Penelitian Makrobenthos dan Aplikasinya. Yogyakarta: Graha Ilmu.

Riniatsih, I. dan Kushartono, W.E. 2009. Subtrat Dasar dan Parameter Oseanografi Sebagai Penentu Keberadaan Gastropoda dan Bilvavia di Panatai Sluke Kabupaten Rembang. Ilmu Kelautan 14(1):50-59.

Ruswahyuni. 2008. Struktur Komunitas Makrozobentos yang Berasosiasi dengan Lamun pada Pantai Berpasir. Jurnal Saintek Perikanan

Syamsurial. 2011. Studi Beberapa Indeks Komunitas Makrozoobentos di Hutan Mangrove Kelurahan Coppo Kabupaten Baru. Skripsi. Program Studi Perikanan Fakultas Ilmu Kelautan dan Perikanan Universitas Hasanudin. Makassar.

Ulum, M. M., Widianingsih \& Hartati, R. 2012. Komposisi dan Kelimpahan Makrozoobenthos Krustasea di Kawasan Vegetasi Mangrove Kel. Tugurejo, Kec. Tugu, Kota Semarang. Journal Of Marine Research. 1(2): halaman 243-251.

Yulihatu, M., I WayaN, R., \& Dewa A.A.P. 2019. Struktur Komunitas Makrozoobenthos Sebagai Indikator Kualitas Perairan di Pantai Serangan Provinsi Bali. Journal of Marine and Aquatic Sciences 5(1), 36-43

Zwart de D. and Trivedi R.C. 1995. Taxonomical key for Biological Water Quality Determination. RIVM, Bilthoven, The Netherlands and CPCB, Delhi, India. 